Daniela Matušíková

https://orcid.org/0000-0002-6141-7454

Milena Švedová

https://orcid.org/0000-0003-1686-2476

Tünde Dzurov Vargová

https://orcid.org/0000-0002-6167-2359

University of Prešov in Prešov

Faculty of Management

Department of Tourism and Hotel Management

daniela.matusikova@gmail.com, milena.svedova@unipo.sk, tunde.dzurov.vargova@smail.unipo.sk

Patrycja Żegleń

https://orcid.org/0000-0002-6815-6488

University of Rzeszów

Institute of Economics and Finance

pzeglen@ur.edu.pl

\title{
AN ANALYSIS OF THE EUROPEAN CITY OF SPORTS PROJECT AND ITS IMPACT ON THE DEVELOPMENT OF TOURIST ACTIVITY: THE EXAMPLE OF SELECTED SLOVAKIAN CITIES
}

\begin{abstract}
The paper presents the issue of sports activity development in the context of the European City of Sports project in selected Slovakian cities: Košice, Banská Bystrica and Nitra. It is an analytical overview aiming at the development of these cities for tourism through the organisation of international sporting events. Using several methods, especially comparison, the authors analyse certain activities and other sports-related issues. The events and activities not only contributed to the development of sport but also supported tourism in the region. A review of the literature on the subject demonstrates the importance and basic assumptions of the European City of Sports as a popular project. The comparative analysis has enabled the authors to present its results in each of the three Slovakian cities.
\end{abstract}

Keywords: European City of Sports, Košice, Banská Bystrica, Nitra, sports tourism.

\section{INTRODUCTION}

Sport and sports activities should play an important role in the life of any population. However, a modern lifestyle and the high demands of the workplace do not allow much time to be saved for sport (Uher, Švedová, Šenková, 2013). Children more and more often prefer spending their leisure time in a passive way. Therefore it is becoming increasingly necessary to develop sporting activities and opportunities. On the other hand, it is crucial to create proper conditions for these activities to take place and this should be the responsibility of cities and their representatives and authorities in cooperation with private sector organizations. Every town or city should provide appropriate conditions for the self-fulfilment of children, the young and adults.
The tourism industry and its related activities are also very important when we consider the development of sport. Generally speaking, tourism plays a significant role in the development of a national economy, therefore each country should make an effort to help develop this industry effectively (Šenková, Šambronská, 2014). Tourism in the $21^{\text {st }}$ century is attributed to many spheres of life, confirming its universality, affecting not only economic but also social aspects. Tourism makes travelling possible, enables tourists to gain new experiences, travel without disability barriers, escape from everyday routine and stereotypes, act independently and increase knowledge (Šambronská, Matušíková, Gallo, Šenková, Mitríková, 2016). Tourism has strong connections with 
sport and recreation. It is also an important attribute of economic development in Slovakia, especially in the region of Košice (Uher, Švedová, Šenková, 2013). Unfortunately, the current GDP of Slovakia (2.5\%) indicates that the country lags behind others in the EU. On the other hand, its strong primary and secondary potential points to existing opportunities. Sport has always been considered as a motivation to travel therefore, tourism might also be taken into account while organizing sports events because they can increase its importance and popularity.

Sports experts claim that sport is becoming a standard and necessary part of our lives today and the trend is to put it in the forefront. It is important to show people that sport brings positive aspects into their daily routine. For some it is a part of life, for others it is a kind of entertainment, hobby or just occasional fun.

Present-day sport plays an important role in our lives and it is a rapidly growing and increasingly attractive phenomenon. Sport and the travel industry go handin-hand. Whether it is fans attending a match or an event, or teams and officials travelling to fixtures or competitions, sports tourism is certainly one of the fastest-growing niches of the travel industry. It is not just World Cups, Olympics and big events that are driving the sector, but also team travel, school sports and smaller competitions. It is worth underlining that sport has a lot in common with tourism. They are of course different because sport involves rivalry, whereas tourism does not but there are more similarities than differences between them.

\section{A REVIEW OF THE LITERATURE ON THE SUBJECT}

When analysing sports tourism, it should be remembered that there are many definitions of this phenomenon according to different perspectives. Below, the authors present some definitions of sports tourism to show what they have in common and the relationships between them.

Sports tourism is a type of tourism activity which refers to the travel experience of the tourist who either observes as a spectator or actively participates in a sporting event, generally involving commercial and non-commercial activities of a competitive nature (UNWTO, 2018).

Whether we talk about sport as a professional, amateur or leisure activity, all types involve travel. Perric (2010) states that sports tourism is a sociological phenomenon which has developed in the last decade and is considered to be the fastest growing sector in the global travel and tourism industry. Redfern (2016) points out that sports tourism refers to travel which involves either observing or participating in a sporting event, staying away from one's own environment. Sport is a fast-growing area in tourism and the industry earns around $\$ 600$ billion annually. This kind of tourism also benefits local inhabitants who are involved in providing tourist services. Another author (Butowski, 2016, p. 90) claims that "there is no such thing as sports tourism" from the ontological point of view. However, the same author admits that there are various forms of tourism related to sports activities and it is somehow justified to use such a term. This literature review has enabled the authors of this paper to conclude that it is very difficult to reach an agreement in discussion concerning the validity of any sports tourism definition. Another author (Alejziak, 2016) claims that it is disputable whether the term (sports tourism) should be distinguished as a separate category. According to some academics (Kaganek, 2015), sports tourism is also defined as "active tourism" differing from sport. Nevertheless, the phenomenon is developing rapidly and it brings more and more benefits, both social and economic, so it seems a legitimate area of discussion.

As it was mentioned, sports tourism brings significant benefits to destinations which host sporting events. The main advantages are economic, both direct and indirect. Direct spending by tourists at sports facilities, hotels, restaurants and entertainment venues stimulates local economies. Jobs are created and tax revenue is earned. Notable sporting events may also improve the image of the areas in which they are organized and the opportunities they offer. These areas attract visitors and the money they will spend there; a desirable effect for many cities (Hassan, 2019).

The authors note that sports tourism is actually one of the most important tourism sectors overall. One of its main points is active recreation and participation in sports activities. Sports tourism represents a wide spectrum of activity; it involves a short or long stay connected mainly to the sport. However, it does not have to be only active sport, it can also be passive, when we travel to a selected sporting event to support our favourite athletes, or simply enjoy that particular sport. In general, sports tourism is divided into domestic and foreign, performance and competition, recreation and relaxation (Ross, 2001).

Sports events of various kinds and scale attract tourists as participants or spectators. Therefore, destinations try to add local flavour to distinguish themselves and provide authentic local experiences. Great sporting events, such as the Olympics or World Cups, can be a tourism development catalyst, provided destination branding, infrastructure development and other economic and social benefits are well balanced (Sport Advisory, 2016). These massive tourist events attract millions 
Table 1. Social impacts of sport tourism events

\begin{tabular}{|l|l|}
\hline \multicolumn{1}{|c|}{ Benefits } & \multicolumn{1}{c|}{ Costs } \\
\hline -increase in the level of local interest in the activity associated & $\begin{array}{l}\text { - social problems (crime, prostitution, rowdy bahaviour, } \\
\text { drinking, drug use, violence, vandalism); } \\
\text { with the event; }\end{array}$ \\
- pleasure in experiencing event; & - potential for intercultural misunderstanding; \\
- influence on community pride and increased involvement of & - changing moral values; \\
individuals in community activities; & - dislocation of locals and loss of amenity as a result of noise \\
- the improvement of regional identity that is seen as being & and crowding; \\
closely related to urban renewal; & - commodification and commercialisation of traditional local \\
- entertainment and social opportunities for local residents; & events; \\
- volunteerism - improve local social support networks; & -traffic congestion. \\
- strengthen cultural values and traditions; & \\
- build national identity. & \\
\hline
\end{tabular}

Source: Jönsson, Lewis (2014).

of people and help bring income for local inhabitants. Tourists buy local products, food and souvenirs. The hotel staff, who are usually local, earn salaries and tips, so it can be said that sporting events increase the local economy (Redfern, 2016).

Hosting sporting events during the tourism high season can have an impact on the quality of life of the residents living in the host community. Therefore, in order to successfully assess the influence of such events on social well-being, the perceptions of those who live close to the event should be taken into consideration. Social impact assessments of sports tourism events (Table 1), though seemingly important, are often avoided by academics who give priority to the visible economic benefits of hosting an event. Avoiding a measurement of social impact stems from the limited credibility of this type of assessment, as residents' perceptions can change over time. Regardless of this, the manner in which local residents view a particular event is critical to its long-term success (Jönsson, Lewis, 2014).

\section{METHODS AND METHODOLOGY}

The main aim of the paper is to evaluate the European City of Sports project using the examples of Košice 2016, Banská Bystrica 2017 and Nitra 2018, as well as to observe whether significant tourism development might be linked to organizing more sports events.

Several research methods were used for the purpose of writing the paper, the main one being the structured interview. It was conducted in cooperation with the administrative employees in the cities of Košice and Banská Bystrica, who provided the necessary information concerning the project, as well as additional information that was not a part of the annual report.

The second method was desk research, which provided data regarding specific activities and events organized as part of the project in the cities involved. The main reference document was the annual report providing crucial data and material for analysis. Mathematical and statistical methods were used to evaluate the data and generalize / synthesise it in the form of tables and graphs.

Finally there was comparison of the activities in the cities in question; the authors focused on sports and tourism statistics.

\section{PROJECT ASSUMPTIONS}

ACES Europe is a non-profit association based in Brussels which chooses the European Capital and European City of Sport. ACES Europe allocates these titles in accordance with principles of responsibility and ethics being aware that sport has a strong impact on society and improves the quality of life. ACES Europe has received the recognition of the European Commission in a 'White Paper' and became an official partner of the European Commission in European Sports Week (White paper of the future of Europe, 2019). Both facts point to the recognition of the work and activity of ACES Europe (ACES Europe, 2019c).

According to general information about the project, the title of European Capital of Sport has been given to one European city every year since 2001, similar to the European Capital of Culture. The choice of European Capital of Sport (a city with 500,000 or more inhabitants) is followed by the appointment of several European Cities and Communities of Sport (25,000-499,999 inhabitants), as well as several European Towns of Sport (up to 25,000 inhabitants) - see Fig. 1 and Table 2. Since 2013, the category of best European sports facility has been included in the project. While the European Capital of Sport title is given to only one city for a year, it is necessary to apply for it together with several other cities across Europe (O projekte EMŠ, 2016). 


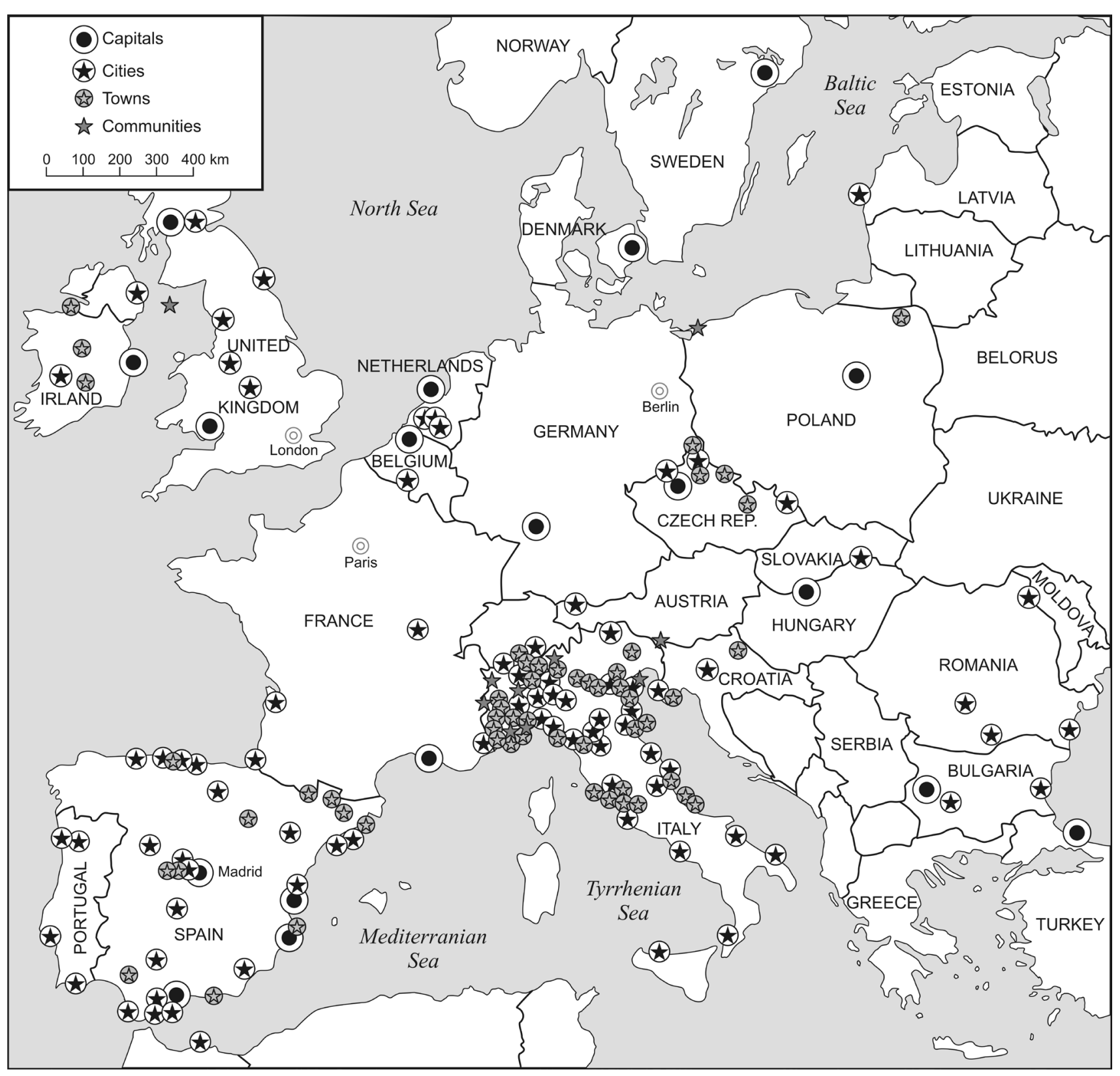

Figure 1. The European Capitals and Cities of Sport Federation Source: ACES Europe (2019a)

The aim of the project is to support sport in the city, sporting activity and its further development (ACES Europe, 2019b).

To be awarded a title by ACES Europe means:

- international recognition,

- city visibility,

- participation in the largest network of cities of sport in Europe,

- sharing experiences between members,

- participation in congresses and conferences held during the year,

- opportunity to apply for a range of EU grants with other cities,

- improvement in urban sports policy.
Table 2. ACES Europe projects and their logotypes

\begin{tabular}{|c|l|l|}
\hline \multicolumn{2}{|c|}{ European Capitals and Cities of Sport Federation } \\
\hline \multicolumn{1}{|c|}{ Type } & \multicolumn{1}{|c|}{ Description } \\
\hline $\begin{array}{l}\text { European } \\
\text { Capital of Sport }\end{array}$ & $\begin{array}{l}\text { a city with } 500,000 \\
\text { or more inhabitants }\end{array}$ \\
\hline $\begin{array}{l}\text { European City } \\
\text { and Community } \\
\text { of Sport }\end{array}$ & $\begin{array}{l}\text { with } 25,000 \\
\text { to } 499,999 \\
\text { inhabitants }\end{array}$ & \\
\hline
\end{tabular}




\begin{tabular}{|c|c|c|}
\hline Type & Description & Logo \\
\hline $\begin{array}{l}\text { European Town } \\
\text { of Sport }\end{array}$ & $\begin{array}{l}\text { with less than } \\
25,000 \text { inhabitants }\end{array}$ & european town of sport \\
\hline $\begin{array}{l}\text { European } \\
\text { City of Sport } \\
\text { of the year }\end{array}$ & $\begin{array}{l}\text { one of the award- } \\
\text { winning cities will } \\
\text { receive this award, } \\
\text { based on the evalua- } \\
\text { tion by an indepen- } \\
\text { dent body taking } \\
\text { into account } \\
\text { the city's } \\
\text { overall activity }\end{array}$ & of sport \\
\hline $\begin{array}{l}\text { European Sport } \\
\text { and Healthy } \\
\text { Company }\end{array}$ & $\begin{array}{l}\text { public recognition } \\
\text { of companies that } \\
\text { promote sport and } \\
\text { health among their } \\
\text { employees }\end{array}$ & \\
\hline $\begin{array}{l}\text { World Capital } \\
\text { of Sport }\end{array}$ & $\begin{array}{l}\text { a format similar to } \\
\text { the European } \\
\text { Capital of Sport, } \\
\text { but outside Europe }\end{array}$ & world capital of sport \\
\hline
\end{tabular}

Source: authors.

\section{KOŠICE - EUROPEAN CITY OF SPORT 2016}

Košice was the first city in Slovakia to be awarded the European City of Sport title in 2016 (Fig. 2). One year later, it was Banská Bystrica and in 2018 Nitra.

In 2015, Košice was allocated 4.6 points out of 5 as a city competing for the title of European City of Sport, in the category of up to 500,000 inhabitants. Košice had pursued this goal systematically since a visit to Ostrava, a partner town, in February 2014. Ostrava had received the title that year and invited representatives from Košice to present their sports activity at the International Conference on Sports. The time needed to prepare for the event meant a thorough analysis of all sporting events organized by sports organizations and clubs, including the involvement of individuals and infrastructure used for all-year-round physical activities.

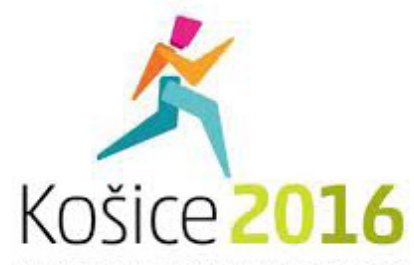

\section{EUROPEAN CITY OF SPORT}

Figure 2. Košice

- European City of Sport 2016 logo

Source: Ciele projektu EMŠ (2016)
Košice representatives visited selected sports facilities, participated in several sporting competitions and non-competitive events, including mass ones. During those visits, the city's genuine interest in engaging in the competition for the title was verified. At the press conference held during the Lukáš Vorela observation mission in Košice, the ambition of the city of Košice to apply for an ECS title in 2016 or 2017 was strongly supported.

Košice - European City of Sport 2016 aimed to attract the largest number of inhabitants of all ages, as well as visitors, to sport. By offering interesting activities, the city wanted to address those who had not been active in sport before or only sporadically. The disabled and the elderly also played an important role, alongside the socially disadvantaged to whom the activities included in the project were offered free of charge. At the same time, the goal was to make the city of Košice visible, both at home and abroad. By announcing its candidacy, the city received offers from federations and international associations to organize various sports events which had an undeniably positive economic effect, providing sporting experience and motivating young people to take up a wide variety of sporting activities (Ciele projektu EMŠ, 2019).

\section{BANSKÁ BYSTRICA - EUROPEAN CITY OF SPORT 2017}

Banská Bystrica had declared an interest in competing for the title of European City of Sport 2017 two years earlier, i.e. in 2015. On 24 March 2015, the city council approved the candidacy and expressed its support for this project. ACES Europe Secretary General, Hugo Alonso (Banská Bystrica, 2019) visited Banská Bystrica in February 2016. Preparations for the competition included a call for tenders for the design of the Banská Bystrica - EMŠ 2017 logo (Fig. 3).

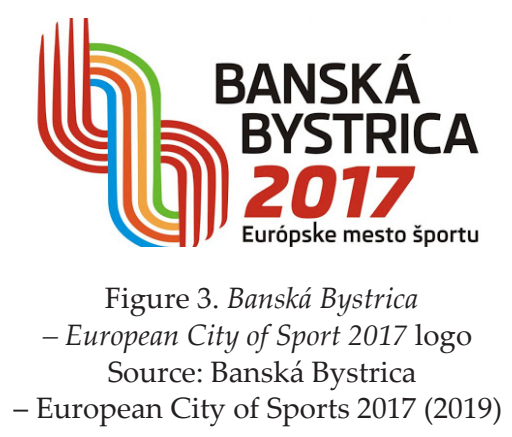

A project team was assembled in order to set the timetable and allocate responsibilities for the tasks, decide on the image of the candidacy, establish communications 
with the public, plan the campaigns and provide necessary documents. The team consisted of the project team leader (vice-president of Banská Bystrica), the EMŠ 2017 project manager and the Head of the Sports Department (Banská Bystrica Region, 2018).

The title greatly increased the attractiveness of sport in Banská Bystrica and became an important milestone in the city's sporting history, while also showing a commitment to its inhabitants (Bystricoviny.sk, 2019). During the year when Banská Bystrica held the title of European City of Sport (2017), it was represented by twelve popular athletes whose achievements had made the city visible in Slovakia and internationally. Olympic, World and European champions and athletes representing Banská Bystrica were great role models for all the inhabitants, especially for the young (Banská Bystrica Region, 2018).

\section{NITRA - EUROPEAN CITY OF SPORT 2018}

Nitra applied for the European City of Sport title in 2017. The city strived to attract as many inhabitants and visitors of all ages as possible. It also wanted to attract those who had not been involved in sport before or rarely engaged in sporting activity.

The candidacy process began in March 2018, when a letter was sent to the ACES Europe Secretariat, declaring the wish to stand for the European City of Sport title. The city requested the support of several institutions, such as the Ministries of Education, Science, Research and Sport of the Slovak Republic, Slovak Olympic Committee, Slovak Paralympic Committee, Slovak Ice Hockey Association, Slovak Football Association, Sports Association for All and Slovak University Sports Association. Nitra sports clubs were also addressed. In May 2017, the European City of Sport logo competition took place. It involved five competitors who submitted several graphic designs. The jury chose the design by Tomáš Belovič (Fig. 4). The logo was used in the year when Nitra was competing for the title of a European City of Sport and throughout 2018 (Mesto Nitra, 2019).

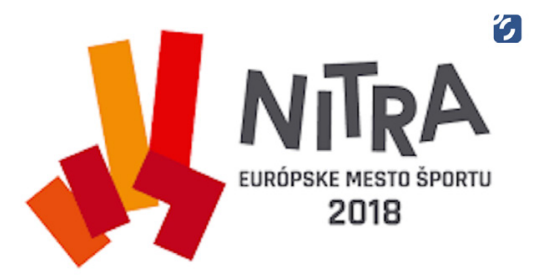

Figure 4. Nitra-European City of Sport 2018 logo Source: Šport.sk (2019)

\section{THE EUROPEAN CITY OF SPORT PROJECT IN NUMBERS}

The eligibility criteria have been established by ACES Europe to have a thorough understanding of how the candidate cities are promoted through sport, as well as ACES Europe values: enjoyment found in exercise, willingness to achieve, sense of community, learning fair play and improvement of health.

In this part of the paper, the authors present several outcomes and interesting facts concerning the three Slovakian destinations which have held the European City of Sport title.

\subsection{PROJECT PARTNERS}

The European City of Sport 2016, 2017 and 2018 projects were realized thanks to the financial support of several partners representing different spheres (Fig. 5) who provided sponsorship and packages. The Košice - European City of Sport 2016 project was implemented due to financial support of 460,000 euros. In Banská Bystrica, one of the first partners for the EMŠ 2017 project was EUROMOTOR which provided four Škoda vehicles with the logo Banská Bystrica EMŠ 2017 and regularly refilled petrol, totalling 5000 euros. Other partners contributed 59,000 euros.

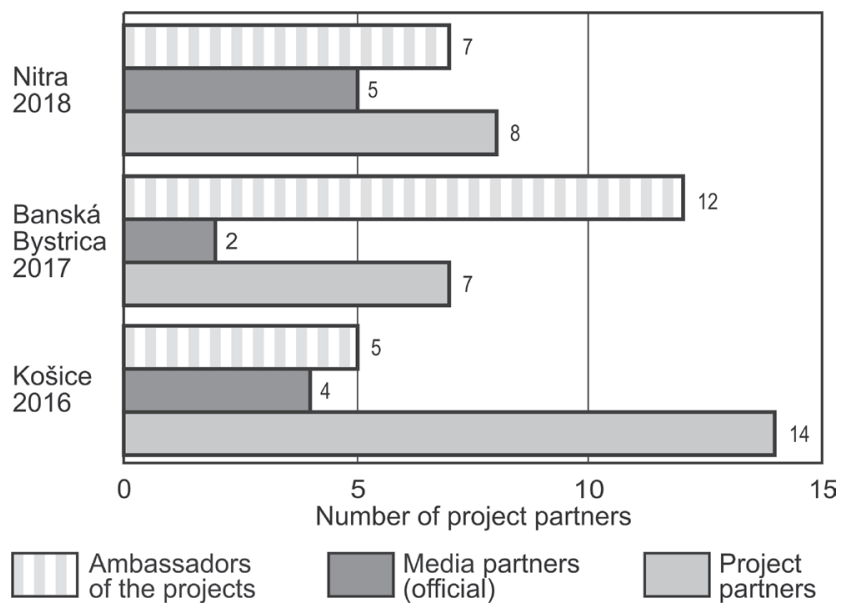

Figure 5. Number of project partners

Source: authors' elaboration, based on annual report

\subsection{RESEARCH RESULTS}

The European City of Sport project was oriented towards sports activities where the public is invited to participate. At the beginning, it is important to point out the results of the events that were held in the three cities in respective years. 
The largest number of events during the year was organized in Nitra (305), followed by Banská Bystrica (229) and Košice (191) - see Fig. 6. An overview of the competitions and sporting events is presented in Table 3.

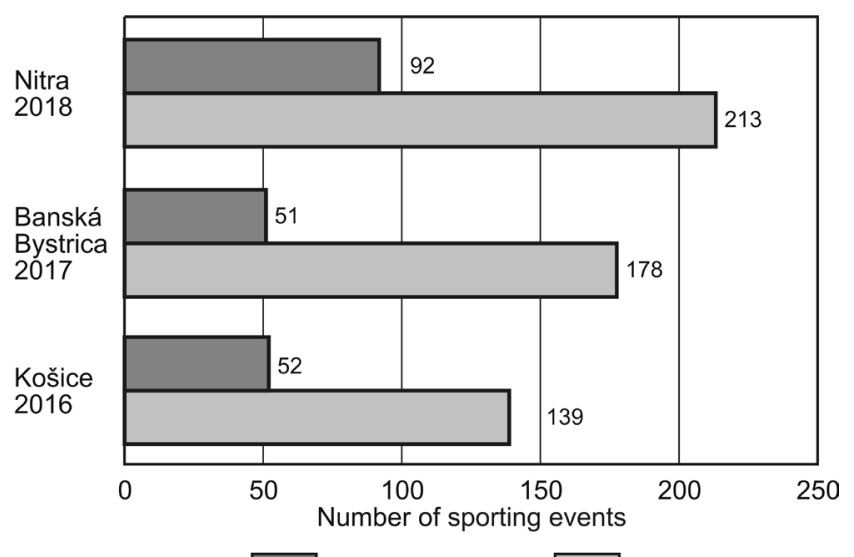

Sporting events

international

national (regional)

Figure 6. An overview of competitions / sporting events in the European City of Sport project

Source: authors based on EMS Košice (2019)

Table 3. Sporting events held in European Cities of Sports

\begin{tabular}{|l|c|c|}
\cline { 2 - 3 } \multicolumn{1}{c|}{} & \multicolumn{2}{c|}{ Overview of sporting events } \\
\hline City of Sport & $\begin{array}{c}\text { National } \\
\text { (regional) }\end{array}$ & International \\
\hline Košice 2016 & 139 & 52 \\
\hline Nitra 2018 & 178 & 51 \\
\hline \multicolumn{1}{|c|}{ City of Sport } & 213 & 92 \\
\hline Košice 2016 & \multicolumn{2}{c|}{ Nutional } \\
(regional) & International \\
\hline Banská Bystrica 2017 & 208,863 & 72,866 \\
\hline Nitra 2018 & 37,276 & 10,126 \\
\hline
\end{tabular}

Source: authors.

The most interesting sporting events during the Košice - European City of Sports 2016 included the Runway run, the Spartan race in the centre of Košice, 'Discover your City by running', Sports Sundays in parks, Sports Fridays on the main street, Summer and Winter Senior Olympics (with over 300 participants whose mean age was 72), Football Connects, tournaments for Roma (gypsies), homeless people, students and local authorities. Sport without Barriers for the disabled including on wheelchairs, "Quadrille-Quadruple", "Retrospartakiá$\mathrm{da}^{\prime \prime}$, Jumps in the City Centre (jumping on bikes, skis and snowboards). The largest number of participants $(116,985)$ was recorded in May.
In Banská Bystrica, most events for amateur athletes were organized between May and September. A very important target group were disadvantaged athletes who suffered from physical, mental or combined handicaps. The city of Banská Bystrica tried to organize various interesting events for this target group not only in 2017 as European City of Sport, but every year.

Monitoring the all-year-round sporting events in Banská Bystrica showed that up to 18,400 registered athletes were actively involved in sports competitions at local, regional and international level during the year. In addition, there were 2400 people taking part in ice hockey, football and basketball league games and 1280 children and young athletes registered at major clubs, such as the UMB, the UMB Swimming Club, the BK ŠKP 08 Youth, or the Dukla BB. There were 22,160 athletes altogether. Recreational sports had even higher numbers. More than 37,200 people in Banská Bystrica participated in recreational and sporting events for disadvantaged groups. This number includes individual and team athletes who use a gym, indoor swimming pool or ice rink. The data on attendance and the use of sports facilities was provided by ZAaRES (Slov. Záhradnícke a rekreačné služby - Gardening and Recreation Services) and MBB (Slov. Mestský úrad Banská Bystrica - Banska Bystrica Cityhall). The large number of public sporting activity enthusiasts in Banská Bystrica includes those who do inline skating, walk on cross-country trails in the city and its surroundings, and the use of the cycling bus service in the summer season and the ski bus in winter.

Fig. 7 presents the proportion of active participants who took part in international, national and regional events within the framework of the City of Sport project. Most participants will know of Košice - the City of Sport 2016 because it is the second largest city and held events such as the World Championship Latin Senior,

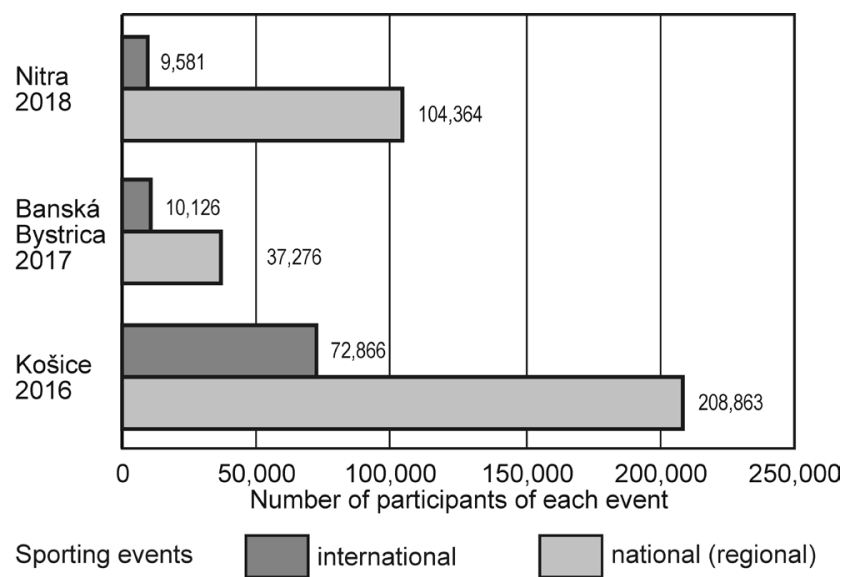

Figure 7. The number of the European City of Sport project participants Source: authors 
World Water Ski Championship, Water Polo Euro Cup, 'Good Angels Košice' - European Women's Basketball League, and the International Peace Marathon. The total number of athletes registered at Nitra sports clubs exceeds 5087 , which is $6.41 \%$ of the population and they competed in events organized in all three European Cities of Sport.

\subsection{TOURISM STATISTICS}

The statistics show that in 2016, in terms of tourist volume, Košice was $5^{\text {th }}$ as regards the number of guests in accommodation establishments, compared to other Slovak regions (Table 4).

Košice websites (Travel in Slovakia, 2019) point to a sharp increase in 2016, so it was important to maintain this trend in the following year. Visitors numbers grew considerably, which increased accommodation revenues rising by over one million euros to nearly 21 million euros in a year. This was the result of the efforts made by all those involved in tourism and was especially positive for the economy of the region in general. Tourism activity can play an important role in the development of the region and that is why it is absolutely essential to pay attention to it.

From the databases available from the Statistical Office of the Slovak Republic, it is clear that the number of guests at the accommodation establishments of a given destination increased in the year when the city held the title of European City of Sport. For evaluation purposes, quadratic regression analysis was used.

2016 was the first and only year for Košice to hold the European City of Sport title because it is allocated for just one year. The increase in the number of tourists in the city was followed by an increase in the number of overnight stays. 2016 was a successful year with significant numbers of tourists. This trend was maintained in the following year and it can be assumed that it was not only general interest that led tourists to the city and the region but also high-quality sporting activities for the public.

2017 recorded a high increase in tourism figures for the Banská Bystrica region, as shown in Table 3, the number of visitors doubling compared to 2016, giving an increase in accommodation income. The success was the result of the efforts of all the institutions and organizations which were engaged in the events held in 2017. The figures available from the Statistical Office of the Slovak Republic show that the number of visitors in accommodation facilities increased in the year when Banská Bystrica was the European City of Sport. In Nitra, in the same situation the number of visitors in accommodation facilities increased by over $100 \%$ compared to 2016 and by approximately $40 \%$ compared to 2017.

\section{DISCUSSION}

Sports tourism involves travelling in order to play sport, watch sport, or visit sporting attractions, including competitive and non-competitive activities (Delpy, 1998). Although there are many definitions of sports tourism, Weed and Bull (2004) identify five main categories: participation in sport, tourism with sports content, luxury sports tourism, sporting events and sports workout.

The European City of Sports is a testament to the efficient linking of the economy and sport, demonstrating that the two areas can effectively help each other. The success of this project is evidenced by the fact that every year there are more and more cities interested in this project and willing to invest a lot of money in this and similar schemes.

The year-long program of the European City of Sport project created our cities as new sporting centres in the region. Europe saw, heard and tasted the beauty of a unique combination of tradition and innovation in sport in Slovakia. The authors believe that the combination of sports-related personalities working and living in the cities presented in the article, new sporting events and support from sports organizers from all over Europe, has developed a unique mix of largeand small-scale sporting events, events for the general public, one-time experiences and long-term projects.

To sum up, the fact that European Cities of Sport are selected by the EU Council of Culture Ministers makes the project harder to evaluate. The nominated cities are likely to differ from those which have not been selected.

Table 4. Number of guests at accommodation establishments in Slovakian regions

\begin{tabular}{|l|c|c|c|c|c|c|c|}
\hline \multicolumn{1}{|c|}{ City of Sport } & 2012 & 2013 & 2014 & 2015 & 2016 & 2017 & 2018 \\
\hline Košice region & 401,869 & 314,651 & 260,494 & 266,361 & 347,014 & 366,142 & 386,088 \\
\hline Banská Bystrica region & 283,180 & 400,251 & 384,801 & 448,568 & 245,904 & 569,164 & 627,660 \\
\hline Nitra region & 219,952 & 238,440 & 236,875 & 261,582 & 128,252 & 263,264 & 335,670 \\
\hline
\end{tabular}

Attention: the authors marked in bold the number of visitors in the years when a given destination was a European City of Sport. Source: authors based on the Statistical Office of the Slovak Republic (Štatistický úrad Slovenskej Republiky, 2017). 
For example, ministers of culture may choose cities that are struggling or (alternatively) have just begun to develop, and any differences in outcome may be due to these conditions rather than the ECoS status and the investments that have been made. Furthermore, individuals who live in the nominated regions may represent fundamentally different levels of satisfaction with life or at least different tendencies (How to evaluate sport and culture..., 2020).

\section{CONCLUSIONS}

It is highly significant how Weed and Bull (2004) identify sports tourism benefits. Identifying, attracting and retaining international, national, regional, state and local sports events result in the following:

- stimulating the local economy (direct spending related to the use of sports facilities and services; visitors' and residents' spending on goods and services; employment opportunities, revenue),

- enhancing the image of the area,

- providing outstanding entertainment and, in some instances, an opportunity to participate in sport,

- improving the quality of life.

The concept of sports-related tourism has become more prominent and very interesting for cities in the last few years. The purpose of this paper was to evaluate the activities of the three Slovak cities participating in the European City of Sport project in 2016, 2017 and 2018.

The results show that the implementation of the project evoked a positive reaction in tourism participants and the number of events in individual areas has increased. This has benefited not only the cities, but their regions as well. These results are crucial as a theoretical foundation for future project plans. Sport has always played an important role in the tourism sector, and the results of this study confirm this.

The added value of this project for a city as well as for its region is the sustainable development and preservation of these events for the future. Their character can be changed and their periodicity can be adapted to the needs of the city. In the years discussed in the article, the infrastructural and technical base of tourism at the presented destinations was significantly improved. The number of accommodation establishments and facilities increased to receive more tourists. This was confirmed by the evidently larger number of visitors and overnight stays in the regions in question. Despite the fact that statistics regarding income from tourism were not included, it is worth mentioning that this increased tourism activity gave rise to several activities which motivate visitors to travel to the destinations discussed in the article.

\section{REFERENCES}

ACES Europe (2019a). Retrieved from: http://aceseurope.eu (12.10.2019).

ACES Europe (2019b). About. Retrieved from: http://aceseurope. eu/about/ (12.10.2019).

ACES Europe (2019c). Benefits of awards. Retrieved from: http:// aceseurope.eu/about/benefits-of-awards/ (12.12.2019).

Alejziak, W. (2016). Sports tourism: A contribution to a debate on its definition and research subject matter. Turyzm/Tourism, $26(1), 85-88$

Banská Bystrica (2019). Retrieved from: http://banskabystrica. sk/ (14.09.2019).

Banská Bystrica - European City of Sports 2017 (2019). Retrieved from: http://emsbb.sk/ (12.08.2019).

Banská Bystrica Region (2018). Retrieved from: http://emsbb. sk/ (3.06.2019).

Butowski, L. (2016). Sports tourism: Real or virtual? Turyzm/ Tourism, 26 (1), 89-90.

Bystricoviny.sk (2019). Retrieved from: http://bystricoviny.sk (7.08.2019)

Ciele projektu EMŠ (2016). Retrieved from: https://www.sportkosice.sk/ciele-projektu/ (15.05.2019).

Delpy, L. (1998). An overview of sport tourism: Building towards a dimensional framework. Journal of Vacation Marketing, 4 (1), 4-5. DOI: https://doi.org/10.1177/135676679800400103

EMS Košice (2019). Retrieved from: http://emskosice.sk (13.08.2019).

Hassan, M. (2019). How sports tourism is boosting local economies. The World Financial Review, 1. Retrieved from: https:// worldfinancialreview.com/how-sports-tourism-is-boosting-local-economies/ (1.07.2019).

How to evaluate sport and culture: European Capital of Culture (statistical approach) (2020). Retrieved from: https://whatworksgrowth.org/resources/how-to-evaluate-sport-and-culture-european-capital-of-culture/ (10.01.2020).

Jönsson, C., Lewis, C.C. (2014). Impacts of hosting a sport event in tourism high season. Recreation and Society in Africa, Asia and Latin America. The Play of Time in Sport, 5 (1), 1-18.

Kaganek, K. (2015). Różnorodność pojęć w zakresie aktywnego uprawiania turystyki. In: A. Stasiak, J. Śledzińska, B. Włodarczyk (eds), Wczoraj, dziś i jutro turystyki aktywnej i specjalistycznej (pp. 26-38). Warszawa: Wydawnictwo PTTK „Kraj”.

Košický samosprávny kraj (2015). Stratégia cestovného ruchu Košického kraja do roku 2020. [s.1.]: e-PRO group a. s.

Mesto Nitra (2019). Retrieved from: https://www.nitra.sk/ (20.09.2019).

Ministerstvo hospodárstva SR, (2005). Odbor cestovného ruchu: Regionalizácia cestovného ruchu v Slovenskej Republike. (Regionalization of tourism in Slovak Republic). Retrieved from: https:// www.mhsr.sk/ (1.06.2019).

O projekte EMŠ (2016). Retrieved from: http://www.emskosice. sk/oprojekte (12.05.2019).

Peric, M. (2010). Sports tourism and system of experiences. Tourism and Hospitality Management, 16 (2), 197-206.

Redfern, H. (2016). How do sporting events affect tourism? Retrieved from: https://prezi.com/mxchgfff3wkm/how-do-sporting-events-affect-tourism/ (25.05.2019).

Ross, D.S. (2001). Developing sport tourism. Retrieved from: http:// www.lib.teiher.gr/webnotes/sdo/Sport\%20Tourism/SportTourism\%20Development\%20Guide.pdf (19.05.2019).

Sport Advisory (2016). Sports tourism: What it is and why it's important. Retrieved from: https://sportadvisory.com/sports-tourism-what-it-is-and-why-its-important/ (18.05.2019).

Šambronská, K., Matušíková, D., Gallo, P., Šenková, A., Mitríková, J. (2016). Hotel services - quality base of dimension of service. 
BK 2: Political Sciences, Law, Finance, Economics and Tourism Conference Proceedings, IV, 307-314.

Šenková, A., Šambronská, K. (2014) Hotelový a reštauračný manažment. Preszów: Bookman.

Šport.sk (2019). Retrieved from: https://sport.aktuality.sk/ (10.09.2019).

Štatistický úrad Slovenskej republiky (2017). Regionálna databáza. Retrieved from: https://slovak.statistics.sk/ (1.06.2019).

Travel in Slovakia (2019). Retrieved from: https://slovakia.travel/ en/kosice (17.08.2019).

Uher, I., Švedová, M., Šenková, A. (2013). Úvod do problematiky rekreácie turizmu a sprievodcovskej činnosti. Preszów: Bookman s.r.o.
UNWTO (2018). Sports tourism. Retrieved from: http://marketintelligence.unwto.org/content/sports-tourism (20.05.2020).

Weed, M.E., Bull, C.J. (2004). Sports tourism: Participants, policy and providers. Oxford: Elsevier.

White paper of the future of Europe (2019). Retrieved from: https://ec.europa.eu/commission/future-europe/white-paper-future-europe_en (20.06.2019).

Article received:

10 January 2020

Accpeted:

6 June 2020 